\title{
PROFIL KOLESTEROL SERUM PENDERITA BATU EMPEDU YANG DITEMUKAN PADA PEMERIKSAAN USG DI RSU ANUTAPURA PALU TAHUN 2018-2020
}

\author{
Mukramin Amran ${ }^{1 *}$, Andi Rahayu ${ }^{1}$, Mahlil ${ }^{1}$ \\ ${ }^{1}$ Program Studi Pendidikan Dokter, Fakultas Kedokteran Universitas Alkhairaat, Jl. Diponegoro No. \\ 39 Palu 94221, Sulawesi Tengah, Indonesia \\ "Corresponding author: Telp: +6281524511350 email: a.mukramin@yahoo.com
}

\begin{abstract}
ABSTRAK
Kolesterol dapat menyebabkan supersaturasi empedu di kandung empedu, dalam beberapa lama empedu yang telah mengalami supersaturasi menjadi mengkristal dan mulai membentuk batu. Tujuan penelitian ini untuk mengetahui profil kolesterol serum penderita batu empedu yang ditemukan pada pemeriksaan USG di RSU Anutapura Palu Tahun 20182020. Desain penelitian adalah metode observasional deskriptif dengan pendekatan cross sectional. Penelitian dilakukan pada tanggal 21 Oktober 2020 sampai 31 Januari 2021. Tempat penelitian di bagian rekam medik RSU Anutapura Palu. Jumlah sampel adalah 31 orang penderita batu empedu Tahun 2018-2020. Hasil penelitian yaitu menunjukkan kelompok sampel laki-laki sebanyak $15(30,0 \%)$ dan kelompok sampel perempuan sebanyak $35(70,0 \%)$. Kelompok usia sampel, yang paling banyak di usia dewasa $33(66,0 \%)$, lansia $14(28,0 \%)$, remaja $3(6,0 \%)$, anak-anak $0(0 \%)$. Didapatkan hasil penderita batu empedu yang ditemukan pada pemeriksaan USG pada kadar kolesterol, yang tertinggi pada nilai normal sebesar $32 \%$ dari total sampel atau sebanyak 16 orang disusul dengan kadar kolesterol yang meningkat atau hiperkolesterolemia sebesar $30 \%$ dari total sampel atau berjumlah 15 orang. Kesimpulan penelitian ini menunjukkan penderita batu empedu paling banyak ditemukan pada perempuan usia dewasa dengan kadar kolesterol normal, akan tetapi tidak menutup kemungkinan orang yang hiperkolesterolemia beresiko terkena batu empedu.
\end{abstract}

Kata Kunci: Kolesterol serum, Batu empedu, USG.

\section{ABSTRACT}

Cholesterol can cause bile supersaturation in the gallbladder, over time the supersaturated bile becomes crystallized and begins to form stones. The purpose of this study was to determine the serum cholesterol profile of patients with gallstones found on ultrasound examination at Anutapura Hospital Palu in 2018-2020. The research design is a descriptive observational method with a cross-sectional approach. The study was conducted from October 21, 2020, to January 31, 2021. The research site is in the medical records section of the Anutapura General Hospital, Palu. The number of samples was 31 people with gallstones in 2018-2020. The results showed that the male sample group was 15 (30.0\%) and the female sample group was 35 (70.0\%). The sample age group, the most in the age of adults 33 (66.0\%), elderly $14(28.0 \%)$, teenagers $3(6.0 \%)$, children $0(0 \%)$. The results of patients with gallstones found on ultrasound examination were cholesterol levels, the highest normal value was 32\% of the total sample or as many as 16 people, followed by elevated cholesterol levels or hypercholesterolemia by $30 \%$ of the total sample or 15 people. The conclusion of this study shows that gallstone sufferers are most commonly found in adult women with normal cholesterol levels, but people with hypercholesterolemia may be at risk of developing gallstones.

Keywords: Serum cholesterol, Gallstones, USG. 


\section{PENDAHULUAN}

Batu empedu adalah material atau Kristal yang terbentuk di dalam kandung empedu atau di dalam saluran empedu, atau pada kedua-duanya. Batu empedu merupakan masalah kesehatan yang signifikan dalam masyarakat berkembang, yang memengaruhi $10-15 \%$ populasi orang dewasa. ${ }^{1}$

Batu empedu atau kandung empedu bentuknya seperti kantong, organ berongga yang panjangnya sekitar $10 \mathrm{~cm}$, terletak dalam suatu fossa yang menegaskan batas anatomi antara lobus hati kanan dan kiri. Batu empedu merupakan kantong berongga berbentuk bulat lonjong seperti buah advokat tepat di bawah lobus kanan hati. Kandung empedu mempunyai fundus, korpus, dan kolum. $^{2}$

Batu empedu merupakan penyakit yang paling banyak dikeluhkan oleh masyarakat Amerika Serikat hingga dirawat di rumah sakit. Penyakit batu empedu didiagnosis lebih dari satu juta orang di Amerika Serikat dengan tindakan kolesistektomi sebanyak 700,000 kasus. ${ }^{3}$

Indonesia merupakan negara yang diduga lebih rendah prevalensi penyakit batu empedu bila dibandingkan dengan di negara barat, tetapi dengan adanya kecenderungan pola hidup sedentary kemungkinan di Indonesia pada masa mendatang kasus batu empedu akan menjadi masalah kesehatan yang patut mendapatkan perhatian. ${ }^{4}$

Etiologi batu empedu masih belum diketahui. Satu teori menyatakan bahwa kolesterol dapat menyebabkan supersaturasi empedu di kandung empedu. Dalam waktu beberapa lama, empedu yang telah mengalami supersaturasi menjadi mengkristal dan mulai membentuk batu. ${ }^{2}$ Menurut gambaran makroskopik dan komposisi kimianya, batu saluran empedu dapat diklasifikasikan menjadi kategori mayor yaitu batu pigmen coklat atau batu calsium bilirubinate yang mengandung $\mathrm{Ca}$ bilirubinate sebagai kompenen utama, batu pigmen hitam yang kaya akan residu hitam tak terekstraksi. ${ }^{5}$ Gambaran klinis batu empedu bermacam-macam seperti rasa nyeri dan kolik biler, ikterus, perubahan warna urin dan feses, devisiensi vitamin dan regurgitasi gas. ${ }^{6}$ Pemeriksaan USG abdomen untuk melihat kandung dan saluran empedu merupakan tes diagnostik standar pada pasien yang memiliki kecurigaan kolelitiasis dan pemeriksaan USG ini wajib diperiksa sebelum pasien dioperasi. Ultrasonografi merupakan suatu prosedur non-invasif yang cukup aman, cepat, tidak memerlukan persiapan khusus, relatif tidak mahal dan tidak melibatkan paparan radiasi, sehingga menjadi pemeriksaan terpilih untuk pasien dengan dugaan kolik biliaris. Kriteria kolelitiasis pada USG yaitu dengan terlihatnya bayangan akustik (Acoustic shadowing) dari gambaran opasitas dalam kandung empedu.

Penelitian ini bertujuan untuk mengetahui profil kolesterol serum penderita batu empedu yang ditemukan pada pemeriksaan USG di RSU Anutapura Palu Tahun 2018-2020.

\section{METODE PENELITIAN}

Desain penelitian yang digunakan adalah metode observasional deskriptif dengan pendekatan cross sectional yang bertujuan untuk gambaran profil kolesterol serum penderita batu empedu yang ditemukan pada pemeriksaan USG di RSU Anutapura Palu Tahun 2018-2020.

Penelitian ini dilakukan pada tanggal 21 oktober 2020 sampai dengan 31 januari 2021. Tempat penelitian yaitu Tempat penelitian di bagian rekam medik RSU Anutapura Palu. Populasi penelitian adalah semua Semua Pasien yang dirawat jalan dan dirawat inap yang melakukan pemeriksaan di bagian laboratorium dan bagian Radiologi RSU Anutapura Palu Tahun 2018-2020.

Subyek penelitian adalah Semua Pasien yang melakukan pemeriksaan di ruang Laboratorium dan Radiologi RSU Anutapura palu yang memenuhi kriteria inklusi. Kriteria Inklusi penelitian adalah pasien yang telah didiagnosis menderita batu empedu yang menjalani pemeriksaan di bagian laboratorium dan radiologi RSU 
Anutapura Palu, laki-laki dan perempuan, dan semua usia. Kriteria Eksklusi penelitian adalah status pasien penderita batu empedu yang tidak lengkap.

Metode pengambilan sampel menggunakan cara consecutive sampling. Jumlah sampel yang didapatkan pada penelitian ini adalah 50 pasien yang melakukan pemeriksaan di ruang Laboratorium dan Radiologi RSU Anutapura Tahun 2018-2020 namun hanya 31 orang yang melakukan pemeriksaan kolesterol serum.

Analisis data dilakukan secara deskriptif yang hasilnya berupa frekuensi dan persentase (proporsi) gambaran karakteristik sampel, profil kolesterol serum, karakteristik kadar kolesterol serum berdasarkan kelompok jenis kelamin. karakteristik kadar kolesterol serum berdasarkan kelompok usia di RSU Anutapura Palu Tahun 2018-2020.

\section{HASIL DAN PEMBAHASAN}

\section{HASIL}

Data yang diperoleh terdiri dari gambaran karakteristik sampel (jenis kelamin dan usia pasien), profil kolesterol serum, karakteristik kadar kolesterol serum berdasarkan kelompok jenis kelamin. karakteristik kadar kolesterol serum berdasarkan kelompok usia.

Tabel 1. Karakteristik sampel penelitian pada pasien penderita batu empedu

\begin{tabular}{llcc}
\hline No & $\begin{array}{c}\text { Karakteristik } \\
\text { sampel }\end{array}$ & $\begin{array}{c}\text { Jumlah } \\
(\mathrm{n})\end{array}$ & $\begin{array}{c}\text { Persentase } \\
(\%)\end{array}$ \\
\hline 1 & Jenis kelamin & & \\
\hline \multicolumn{2}{l}{ a. Laki-laki } & 15 & 30 \\
\hline & b. Perempuan & 35 & 70 \\
\hline Total & 50 & 100 \\
\hline 2 & Usia & & \\
\hline & a. Dewasa & 33 & 66 \\
\hline & b. Lansia & 14 & 28 \\
\hline & c. Remaja & 3 & 6 \\
\hline d. Anak-anak & 0 & 0 \\
\hline Total & 50 & 100 \\
\hline
\end{tabular}

Berdasarkan penelitian kepada 50 subjek penelitian pada Tabel 1 menunjukkan bahwa kelompok sampel laki-laki sebanyak $15(30 \%)$ dan kelompok sampel perempuan sebanyak 35 (70\%). Sedangkan kelompok usia sampel, yang paling banyak di usia Dewasa 33 (66\%), Lansia 14 (28\%), Remaja $3(6 \%)$, Anak-anak $0(0 \%)$.

Dari Tabel 2 didapatkan dari 50 penderita batu empedu diperoleh persentase hasil berdasarkan karakteristik kolesterol serum pada penderita batu empedu berdasarkan jenis kelamin, kolesterol serum yang normal pada laki-laki sebanyak 5 orang $(31.3 \%)$ dan diikuti oleh perempuan sebanyak 11 orang $(68.8 \%)$, sehingga total pada kolesterol serum yang normal sebanyak 16 pasien (100.0\%). Hasil berdasarkan karakteristik kolesterol serum yang meningkat atau hiperurisemia pada laki-laki ada 4 orang (26.7\%) diikuti oleh perempuan ada 11 orang $(73.3 \%)$ dimana perempuan lebih beresiko terkena batu empedu yang kadar kolesterolnya meningkat atau hiperurisemia dan total pada kolesterol yang meningkat sebanyak 15 orang (100.0\%). Jadi karakteristik kadar kolesterol serum pada penderita batu empedu berdasarkan jenis kelamin sebanyak 31 sampel.

Tabel 3 menunjukkan dari 31 penderita batu empedu diperoleh persentase hasil berdasarkan karakteristik kolesterol serum pada penderita batu empedu berdasarkan kelompok usia, kolesterol serum yang normal pada dewasa sebanyak $10(62,5 \%)$, dan diikuti oleh lansia sebanyak $6(37,5 \%)$, dan pada usia remaja tidak terapat atau 0 pasien $(0.0 \%)$ sehingga total pada kolesterol serum yang normal sebanyak 16 pasien $(100.0 \%)$. Hasil berdasarkan karakteristik kolesterol serum yang meningkat atau hiperurisemia pada dewasa ada 13 orang $(86,7 \%)$ diikuti oleh lansia ada 2 orang $(13.3 \%)$ dan pada usia remaja tidak terdapat atau 0 orang $(0.0 \%)$ dimana dewasa lebih beresiko terkena batu empedu yang kadar kolesterolnya meningkat atau hiperurisemia dan total pada kolesterol yang meningkat sebanyak 15 orang $(100.0 \%)$. Jadi pada karakteristik kadar kolesterol pada batu 
empedu berdasarkan kelompok usia sebanyak 31 orang.

Tabel 2. Karakteristik sampel penelitian kadar kolesterol serum berdasarkan jenis kelamin

\begin{tabular}{ccccc}
\hline \multirow{2}{*}{ No } & \multirow{2}{*}{ Kolesterol Serum } & \multicolumn{2}{c}{ Jenis Kelamin } & \multirow{2}{*}{ Total } \\
\cline { 3 - 4 } & Laki-laki & Perempuan & \\
\hline 1 & Normal & $5(31,3 \%)$ & $11(68,8 \%)$ & $\begin{array}{c}16 \\
(100 \%)\end{array}$ \\
\hline 2 & Hiperkolesterolemia & $4(26,7 \%)$ & $11(73,3 \%)$ & $\begin{array}{c}15 \\
(100 \%)\end{array}$ \\
\hline & Total & $9(29 \%)$ & $22(71 \%)$ & $\begin{array}{c}31 \\
(100 \%)\end{array}$ \\
\hline
\end{tabular}

Tabel 3. Karakteristik sampel penelitian kadar kolesterol serum berdasarkan usia

\begin{tabular}{llcccc}
\hline \multirow{2}{*}{ No } & \multirow{2}{*}{ Kolesterol Serum } & \multicolumn{3}{c}{ Kelompok Usia } & \multirow{2}{*}{ Total } \\
\cline { 3 - 5 } 1 & Normal & $0(0 \%)$ & $10(62,5 \%)$ & $6(37,5 \%)$ & $\begin{array}{c}16 \\
(100 \%)\end{array}$ \\
\hline 2 & Hiperkolesterolemia & $0(0 \%)$ & $13(86,7 \%)$ & $2(13,3 \%)$ & $\begin{array}{c}15 \\
(100 \%)\end{array}$ \\
\hline \multirow{2}{*}{ Total } & $0(0 \%)$ & $23(74,2 \%)$ & $8(25,8 \%)$ & $\begin{array}{c}31 \\
(100 \%)\end{array}$ \\
\hline
\end{tabular}

Tabel 4. Profil kolesterol serum pada penderita batu empedu

\begin{tabular}{cccc}
\hline No & Kadar Kolesterol & $\begin{array}{c}\text { Jumlah } \\
(\mathrm{n})\end{array}$ & $\begin{array}{c}\text { Persentase } \\
(\%)\end{array}$ \\
\hline 1 & Hiperkolesterolemia & 15 & 48,4 \\
\hline 2 & Normal & 16 & 51,6 \\
\hline \multirow{2}{*}{ Total } & 31 & 100 \\
\hline
\end{tabular}

Dari Tabel 4 diatas, didapatkan hasil penderita batu empedu yang ditemukan pada pemeriksaan USG pada kadar kolesterol, yang tertinggi pada nilai normal sebesar $51,6 \%$ dari total sampel atau sebanyak 16 orang disusul dengan kadar kolesterol yang meningkat atau hiperkolesterolemia sebesar 48,4\% dari total sampel atau berjumlah 15 orang.

\section{PEMBAHASAN}

Berdasarkan analisa data, didapatkan hasil dimana kelompok sampel laki-laki sebanyak 15 (30,0 \%) dan kelompok sampel perempuan sebanyak 35 (70,0\%). Sedangkan kelompok usia sampel, yang paling banyak di usia Dewasa $33(66,0 \%)$, Lansia 14 $(28,0 \%)$, Remaja $3(6,0 \%)$, Anak-anak 0
$(0 \%)$. Hasil dari penderita batu empedu yang ditemukan pada pemeriksaan USG pada kadar kolesterol, yang tertinggi pada nilai normal sebesar 51,6\% dari total sampel atau sebanyak 16 orang disusul dengan kadar kolesterol yang meningkat atau hiperkolesterolemia sebesar $48,4 \%$ dari total sampel atau berjumlah 15 orang.

Hal ini sejalan dengan penelitian yang dilakukan oleh Sakti Perwira (2020) dimana jenis kelamin perempuan mempunyai resiko lebih besar menderita batu empedu dibandingkan dengan jenis kelamin laki-laki. Hal ini dikarenakan oleh hormone esterogen yang berpengaruh terhadap peningkatan eskresi kolesterol oleh kandung empedu. Dilanjutkan hasil penelitiannya juga yaitu dimana usia berisiko 
(>40 th) akan memiliki risiko 0,22 kali lebih besar untuk menderita batu empedu dibandingkan dengan responden dengan usia tidak berisiko (<40th). Penelitian ini mendukung teori bahwa penyakit batu empedu sering terjadi pada orang dewasa usia 40-60 tahun, dan jarang ditemui pada usia remaja,disebabkan karena peningkatan saturasi empedu karena terjadi penurunan aktivitas 7a hidroksilase yang merupakan enzim limiting rate untuk biosintesis kolesterol. $^{7}$

Pada penelitian yang dilakukan oleh Made Agus (2014) dimana didapatkan hubungan yang bermakna $(p=0,001)$ peningkatan kadar kolesterol merupakan resiko potensial untuk terjadinya batu empedu, dimana orang yang memiliki peningkatan kadar kolesterol mempunyai resiko potensial menderita batu empedu, pembentukan batu empedu adalah kristalisasi, pengendapan kristal kolesterol memulai pembentukan batu empedu,ketika empedu pada kandung empedu menjadi jenuh dengan kolesterol, maka terjadi nukleasi, flokulasi dan pengendapan Kristal kolesterol, keadaan ini menyebabkan inisiasi pembentukan batu empedu. ${ }^{8}$ Pada penelitian yang dilakukan oleh S selcuk A (2013) dimana 30 pasien $26(86,7 \%)$ memiliki kadar kolesterol serum tinggi, dan mereka memiliki kadar kolesterol batu yang lebih tinggi secara signifikan lebih banyak bila dibandingkan dengan pasien dengan kadar kolesterol serum normal atau rendah $18(40.0 \%) .^{9}$ Demikian pula, konsentrasi kolesterol batu rata-rata pada pasien dengan kolesterol serum tinggi secara signifikan lebih tinggi daripada yang lain, Andreotti et al berpendapat bahwa kadar kolesterol serum tinggi berkorelasi positif dengan penyakit batu empedu. ${ }^{10}$ Pada penelitian yang dilakukan oleh Sikandar Hayat (2019) Dimana sebanyak 100 orang direkrut dalam penelitian ini, dimana 50 adalah pasien dan 50 adalah kontrol. Usia rata-rata pasien adalah 40,90 tahun dan kontrol adalah 34,74 tahun. Dalam penelitian tersebut, 46 pasien adalah perempuan dan 44 kontrol adalah perempuan, dengan hasil menunjukkan bahwa pasien dengan kadar kolesterol serum tinggi lebih banyak $184,60 \quad(37,65)$ dibandingkan dengan pasien dengan control 181,08 (33,97). Jika terjadi kelebihan kolesterol atau berkurangnya fosfolipid dan / atau asam empedu, terbentuk vesikula multi lamelar yang menyebabkan nukleasi kristal kolesterol yang mengarah pada pembentukan batu. Sekresi empedu litogenik supersaturasi kolesterol, penurunan konsentrasi fosfolipid, dysmotility kandung empedu, penundaan waktu transit usus besar (mendukung reabsorpsi asam deoksi-kolat), dan reseksi ileum (menghabiskan kumpulan asam) semuanya telah terlibat dalam pembentukan batu empedu. ${ }^{11}$

Pada penelitian yang dilakukan oleh Sakti Perwira (2020) tidak sejalan dengan penelitian karena terjadi peningkatan antara batu empedu dengan kadar bilirubin.karena bilirubin adalah pigmen kuning yang merupakan hasil pemecahan sel darah merah yang disekresikan kedalam empedu oleh sel hepar sehingga menyebabkan bilirubin diekskresi terlalu banyak melalui pemecahan hemoglobin sehingga bilirubin yang berlebihan dapat menyebabkan kolelitiasis. ${ }^{7}$

\section{KESIMPULAN}

Kesimpulan pada penelitian ini yaitu antara lain :

1. Pada penderita batu empedu didapatkan lebih banyak pada jenis kelamin wanita dengan usia dewasa.

2. Pada penderita batu empedu dengan kadar kolesterol serum berdasarkan kelompok usia didapatkan lebih banyak pada orang dewasa dengan kadar kolesterol yang meningkat.

3. Penderita batu empedu dengan kadar kolesterol serum berdasarkan jenis kelamin ditemukan lebih banyak pada jenis kelamin wanita dengan kolesterol serum meningkat.

4. Pada penderita batu empedu didapatkan lebih banyak pada kadar kolesterol yang normal akan tetapi tidak menutup kemungkinan orang yang hiperkolesterolemia berisiko terkena batu empedu karena ada beberapa subjek 
yang hiperkolesterolemia terkjena batu empedu.

\section{DAFTAR PUSTAKA}

1. Stinton LM, Shaffer EA. Epidemiology of Gallbladder Disease: Cholelithiasis and Cancer. Gut Liver. 2012;6(2):172. doi:10.5009/GNL.2012.6.2.172

2. Rahim M. Karakteristik Pasien Kolelitiasis di Rsup Dr. Wahidin Sudirohusodo Makassar Periode Januari-Desember 2012. digilib.unhas.ac.id. Accessed April 19, 2020. http://digilib.unhas.ac.id/uploaded_files/ temporary/DigitalCollection/OTA1ND MwMjVmODY2OTY4Y2ZjMWM3M WI1MDIINGFiMGQyYWVIMTU5MQ $==$.pdf

3. Attasaranya S, Fogel E, America GLMC of N, 2008 U. Choledocholithiasis, ascending cholangitis, and gallstone pancreatitis. Elsevier. 2008;92:925-960. doi:10.1016/j.mcna.2008.03.001

4. Widiastuty AS. Patogenesis Batu Empedu. Syifa' Med J Kedokt dan Kesehat. 2010;1(1):40-54. doi:10.32502/SM.V1I1.43

5. Sudoyo AW. Buku Ajar Ilmu Penyakit. Interna Publishing; 2009.

6. Rau E, Ongkowijaya J, Kawengian V. Perbandingan kadar asam urat pada subyek obes dan non-obes di Fakultas Kedokteran Universitas Sam Ratulangi
Manado. ejournal.unsrat.ac.id. 2015;3(2).

7. Aji SP, Arania R, Maharyuni E. Hubungan Usia, Jenis Kelamin dan Kadar Bilirubin Dengan Kolelitiasis. jurnal.akperdharmawacana.ac.id. 5(2):583.

8. Sueta MAD, Warsinggih W. Faktor Risiko Terjadinya Batu Empedu di RSUP Dr. Wahidin Sudirohusodo Makassar. JBN (Jurnal Bedah Nasional). $\quad$ 2017;1(1):20. doi:10.24843/JBN.2017.V01.I01.P04

9. Atamanalp SS, Keles MS, Atamanalp RS, Acemoglu H, Laloglu E. The effects of serum cholesterol, LDL, and HDL levels on gallstone cholesterol concentration. Pakistan $J$ Med Sci. 2013;29(1):187.

doi:10.12669/PJMS.291.2798

10. Gabriella A, Jinbo C, Yu-Tang G, et al. Serum lipid levels and the risk of biliary tract cancers and biliary stones: A population-based study in China. Int $J$ cancer. 2008;122(10):2322-2329. doi:10.1002/IJC.23307

11. Hayat S, Hassan Z, Changazi SH, et al. Comparative analysis of serum lipid profiles in patients with and without gallstones: A prospective cross-sectional study. Ann Med Surg. 2019;42:11. doi:10.1016/J.AMSU.2019.04.003 